\title{
Food type and temperature constraints on the fitness of a dominant freshwater shredder
}

\author{
Liliana García* and Isabel Pardo \\ Departamento de Ecología y Biología Animal, Universidad de Vigo. Facultad de Ciencias Campus As Lagoas - Marcosende, \\ 36310 Vigo, Spain
}

Received 21 January 2015; Accepted 23 June 2015

\begin{abstract}
Freshwaters receive a large amount of materials and biologically available energy from their surrounding catchments. In particular, small forested streams are dependent on allochthonous organic matter inputs. However, since the middle 20th century large areas of forests in the Iberian Peninsula have been converted to eucalypt plantations, impairing invertebrate communities and stream energy fluxes. In addition, the dependence of organismal metabolic rates on temperature may influence invertebrate life cycles and development, and ultimately the riparian-stream system. We tested the effects of two food resources (alder and eucalypt) under two different temperatures $\left(9\right.$ vs. $\left.14{ }^{\circ} \mathrm{C}\right)$ on the life history parameters and elemental composition of Brillia bifida (Chironomidae), a numerically dominant shredder in forested streams of NW Spain. Our results showed: (i) warmer temperature accelerated the development of B. bifida larvae (i.e., three times faster at warm than at cold temperature), (ii) Brillia's growth rate when fed on eucalypt leaves was only $30 \%$ of what it was on alder leaves, and (iii) both factors together modified larvae stoichiometry and nutrient fluxes (i.e., through fine particulate organic matter production). The observed elemental imbalances suggest, to some extent, a deviation from the "strict homeostasis" assumption for heterotrophs. Differential effects observed on larval development, growth and elemental composition point out that food type and temperature are influencing B. bifida performance, and this fact may reach other trophic compartments through detritivore-mediated nutrient cycling.
\end{abstract}

Key words: Brillia bifida / elemental imbalances / food type / life cycle / temperature

\section{Introduction}

Detritus drives the dominant pathway of energy and material flow in forested headwater streams (Fisher and Likens, 1973; Richardson, 1991; Webster et al., 1995; Wallace et al., 1997). Shredding macroinvertebrates convert coarse particulate organic matter $(\mathrm{CPOM})$ to fine particulate organic matter (FPOM) and thus, play a key role in stream functioning (Cummins and Klug, 1979; Wallace and Webster, 1996), by providing a trophic link between the detrital resource base and secondary consumers and predators (Cummins et al., 1989). Currently, anthropogenic impacts on riparian corridors have the potential to transform freshwater ecosystems dramatically by altering the quality, magnitude and timing of litterfall entering streams, stream flows and nutrient fluxes (Cillero et al., 1999; Gomi et al., 2002; Woodward et al., 2010).

*Corresponding author: lilizar@uvigo.es, lilianagarcialago@hotmail.com
On the Iberian Peninsula, deciduous forests have been replaced by monocultures of introduced species, including evergreen eucalypts native to Australia. In total, 1.19 million ha in this region have been planted with eucalypts (mainly in Galicia, Huelva and Portugal), equivalent to $4.3 \%$ of the forest area and $2 \%$ of the total area (Kling, 2012). Eucalypt leaves represent a low-quality resource for stream invertebrates because of their low nitrogen content and hard cuticle. In addition, oil-based and polyphenolic substances contained in mesophyll cells (Canhoto and Graça, 1995, 1999; Canhoto et al., 2002) act as barriers to fungal colonization and shredder consumption, leading to altered detritus processing and shredding activity (Canhoto and Graça, 1995; Abelho and Graça, 1996; Pozo et al., 1998; López et al., 2001) and thus, the structure and functioning of forested headwater streams. There are many studies that have demonstrated how stream invertebrates may evolve developmental adaptations for the utilization of available resources (Rowe and Ludwig, 1991) and/or change their internal elemental 
ratios in response to resource quality (Cross et al., 2003; Small and Pringle, 2010). These responses are manifested at the physiological, behavioural or genetic level and depend on individual requirements (Slansky and Scriber, 1985; Sterner and Elser, 2002; Swan and Palmer, 2006). Therefore, consumers with high body $\mathrm{N}$ or $\mathrm{P}$ content and high growth rates (GR) seem to require food that is high in $\mathrm{N}$ or $\mathrm{P}$, respectively, to maintain optimal growth (Cross et al. 2003; Frost et al., 2005). The extent to which individuals can compensate for elemental imbalances will ultimately determine their life history traits as well as alterations in the nutrient cycling of consumers (Sterner and Elser, 2002).

Temperature is another relevant factor affecting the life history traits of many species (Sweeney and Vannote, 1986,; Hutchens et al., 1997; Graça, 2001). Particularly sensitive are the life cycle (Rowe and Ludwig, 1991), survival (Dieterich and Anderson, 2000), body size (Atkinson, 1994; Hildrew et al., 2007) and GR (Vos et al., 2000) of stream organisms. Forested headwater streams in temperate regions are subjected to seasonal changes of temperature, directly affecting ectothermic consumers by altering their metabolic rates, development time, respiration, growth and consumption, as well as their internal elemental content (Brown et al., 2004; Villanueva et al. 2011; Correa-Araneda et al., 2015; Mas-Martí et al. 2015).

The goal of this study was to investigate the effects of food type (i.e., alder vs. eucalypt) and temperature ( 9 vs. $14^{\circ} \mathrm{C}$, mean stream water temperatures during winter and spring, respectively) on the GR, biomass, FPOM production and elemental content of Brillia bifida Kieffer (Diptera: Chironomidae) under laboratory conditions. $B$. bifida is a numerically dominant shredder inhabiting streams in the Holarctic region, often associated with immersed wood and leaves (Cranston et al., 1983). It has an extremely high secondary production in the study area (García and Pardo, 2012). We hypothesized that (i) the poor-quality of eucalypt leaves would reduce GR and increase resource-consumer imbalances due to their high C:nutrient ratio, (ii) the summer temperature would increase consumers' metabolism, leading to reduced development time and higher GR and (iii) both factors together might doubly constrain detritivore fitness due to the mismatch between metabolic demands and availability of resources.

\section{Methods}

\section{Sampling material}

High- vs. low-quality food types were represented by the recently fallen leaf litter of Alnus glutinosa (L.) Gaertn., and Eucalyptus globulus Labill subsp. globulus, respectively. Leaf litter was collected along Barxa stream $\left(42^{\circ} 2^{\prime} \mathrm{N},-8^{\circ} 72^{\prime} \mathrm{W}\right)$, a typical temperate, second-order, forested headwater in NW Spain. The collection area was surrounded by a riparian buffer composed of eucalypts mixed with native deciduous tree species.

Prior to the set-up of the experiment, alder and eucalypt leaves were submerged in stream water to allow for microbial conditioning. The conditioning was performed over the course of 7 days for alder leaves and 14 days for eucalypt leaves, since the latter are less palatable and some studies have suggested they may develop a similar microbial community to alder leaves if conditioned for long enough (Bärlocher et al., 1995; Canhoto and Graça, 1996; Gessner et al., 1999). Stream water and larvae of B. bifida were also collected, and were transported to the laboratory in aerated containers. For 2 days prior to the experiment, a total of 500 larvae were acclimated to laboratory conditions $(12: 12 \mathrm{~h}$ light:dark photoperiod) without food. Conditioned leaves $(n=3)$ and a subset of the larvae $(n=5$; replicates of three pooled larvae) were used as controls to assess the initial elemental contents among treatments.

\section{Experimental design}

The experiment consisted of the incubation of II-instar B. bifida larvae until their pupation and emergence as adults. The incubation was done in laboratory microcosms which were housed in two temperature-controlled incubators (Microclimate MC1000E-Snijders Scientific, Holland). The microcosms consisted of rectangularshaped plastic chambers of $40 \mathrm{~cm}^{2}$ base and $10 \mathrm{~cm}$ height (total volume of $\sim 400 \mathrm{~mL}$ ). Water in chambers was kept at a constant volume by adding stream water when necessary. Chambers were provided with continuous aeration in a 12:12 $\mathrm{h}$ light:dark period and covered with a chiffon net $(1 \mathrm{~mm}$-mesh net) to prevent the escape of adults.

At the beginning of the experiment, five randomly selected larvae of $B$. bifida were placed in each chamber and fed ad libitum. Larvae were divided among four treatments according to the two different food type resources (alder or eucalypt), and two temperatures ( 9 or $14{ }^{\circ} \mathrm{C}$, the mean stream water temperatures recorded during winter and spring, respectively (García and Pardo, 2012)). For the first 16 days, three chambers per treatment (i.e., replicates) were retrieved every 4 days, without replacement. After the 16th day, the collection procedure varied with temperature: (a) at $9{ }^{\circ} \mathrm{C}$, chambers were retrieved every 8 days due to slow larval development, and (b) at $14{ }^{\circ} \mathrm{C}$, the collection finished at the 20th day due to accelerated development. The complete incubation period then lasted until a maximum of 20-64 days that included a total of 5 and 11 sampling times at 14 and $9{ }^{\circ} \mathrm{C}$, respectively. Then, a total number of 96 microcosms (treatments $\times$ time collection $\times$ replicates) were initially set up in the laboratory.

We estimated B. bifida development, growth, FPOM production and elemental contents of both food resources and consumers during the whole experiment as explained below. 


\section{Development and biomass of $B$. bifida}

We recorded the number of larvae, pupae and adults, and the time until pupation (i.e., onset of pupa) and emergence (i.e., onset of adult) of B. bifida in each treatment. When present, adults were sexed, and the percentage of males and females was determined at the end of the experiment.

At each collection time, leaves were removed from chambers and rinsed on a $100 \mu \mathrm{m}$ mesh net to remove fine detritus and B. bifida individuals. Then, leaves were ovendried for 2 days at $55^{\circ} \mathrm{C}$, weighed and stored until posterior analyses of elemental content (see below). A similar procedure was followed for larvae, but before drying, all were photographed using an Olympus DP10 digital colour camera attached to an Olympus SZX9 binocular microscope (at 40X). Photos were used to determine total body length (BL) (Olympus Microimage Software, v. 4.0 for Windows, Media Cybernetics, Silver Spring, MD, USA), from which we calculated larval biomass (mean dry mass (MDM)) using the length-mass relationships obtained in a previous study (García and Pardo, 2012). Detritivore GR were estimated as $\mathrm{GR}=\left[\left(\mathrm{MDM}_{f}-\mathrm{MDM}_{i}\right) / \mathrm{MDM}_{i}\right] / \#$ days $]$, where $\mathrm{MDM}_{\mathrm{f}}$ and $\mathrm{MDM}_{\mathrm{i}}$ are the final and initial MDM (mg), respectively, divided by the number of days of the experiment (\# days).

\section{FPOM production}

FPOM composed mainly of leaf fragments and faecal pellets were obtained by filtration of the water remaining in the chamber through Whatman $\mathrm{GF} / \mathrm{F}$ filters. Filters were oven-dried for 2 days at $55^{\circ} \mathrm{C}$, weighed and stored until posterior analyses of elemental content (see below).

\section{Elemental content}

Immediately following each round of sample collection, leaves, FPOM and larvae were dried, ground and homogenized using a ball mill (RETSCH MM200) as preparation for the analyses of elemental contents $(\mathrm{C}: \mathrm{N}: \mathrm{P})$. Larvae were weighed to the nearest $0.001 \mathrm{mg}$ (Sartorius micro-M2P scale microbalance, Germany), while leaves and FPOM were weighed to the nearest $0.1 \mathrm{mg}$ (Mettler Toledo AB104 balance, Switzerland). For $\mathrm{C}$ and $\mathrm{N}$ analyses, samples of larvae and leaves were placed in tin capsules and analysed with a Carbo Erba EA $1108 \mathrm{CHN}$ analyser (Fisons Instruments, Italy), while samples of FPOM were analysed with a LECO CN2000 macro-elemental analyser (Fisons Instruments, Italy). For $\mathrm{P}$ analysis, all samples were placed into acid-washed and pre-ashed ceramic crucibles and ashed at $500{ }^{\circ} \mathrm{C}$. Later, FPOM and leaf samples were acid digested (persulfate digestion Grasshoff et al., 1983) and were processed using a continuous flux analyser (AutoAnalyzer3, Bran + Luebbe, Germany). Larvae were acid digested $\left(69 \% \mathrm{HNO}_{3}\right)$ in a LT-100 micro-digestor at $140^{\circ} \mathrm{C}$ until evaporation (Thermostat Dr. Lange, Germany), with $\mathrm{HNO}_{3} 2 \%$ for subsequent determination by atomic absorption (ICP-OES optima 4300 DV, USA). All data were presented either as percentages and/or as molar ratios.

\section{Statistical analyses}

The statistical analyses were performed using $\mathrm{R}$ (Development Core Team, 2012, version 2.15.2). Data were transformed to satisfy assumptions of normality and homoscedasticity when required (Quinn and Keough, 2002). The development (number of larvae, pupae, females and males) and growth of B. bifida individuals were analysed separately by fitting linear models. Following our experimental design, leaf type and temperature were used as main factors. Since five individuals were incubated in the same chamber per treatment, the chamber was used as a random factor. In addition, time (sampling date) was used as a covariate in all models, except in those concerning growth, to account for the whole period of the experiment. Time was also tested as a random factor, but Akaike Information Criterion (AIC) was not improved. Different generalized linear mixed models (GLMMs) (with a random factor), generalized linear models (GLMs) (without a random factor) and linear models (LMs) (for growth only) were run and compared in order to achieve the best model for our data. The best models for each variable are shown in bold in Table 1 . Model selection was done by backward elimination of non-significant factors from the full model which included all interactions by choosing the model with the lowest AIC. Random factors were maintained in the model when they were able to explain a large percentage of the variance (an indication of correlation among individuals). When the contrary was observed, the random factor was deleted, and the significance of the fixed factors was tested with an analysis of variance (ANOVA) applied to the selected model. Because development was measured as presence/ absence, a binomial error distribution was used in the GLMMs (the glmer function in the lme4 package, Bates et al., 2011) to determine whether the development of B. bifida could be linked with food type and temperature.

Elemental composition of leaves and FPOM during the larval incubation period (i.e., from day 0 to day 16) was analysed by fitting LMs with leaf type and temperature as fixed factors and with time as covariate. Testing for differences in larvae was more limited because replicates of each treatment had to be pooled to achieve the minimum required weight for elemental analyses $(\geq 1 \mathrm{mg})$. A Kruskal-Wallis ANOVA was used to test for significant differences in elemental ratios of larvae between different treatments. In addition, we plotted the elemental ratios of larvae and food resources (C:N, C:P and N:P) to check the relative stoichiometric constraints (i.e., elemental imbalances) naturally existing in these ecosystems and go through potential changes due to alterations of 
Table 1. Linear models (generalized linear mixed models (GLMMs), generalized linear models (GLMs) and linear models (LMs)) analysed over the development (i.e., number of larvae, pupae, females and males) and growth rates (GR) of Brillia bifida during their incubation from II-instar larvae to adult emergence. Model selection (GLMMs vs. GLMs/LMs) was done by backward elimination of non-significant factors from the full model including all interactions and taking into account the lowest Akaike information criterion (AICs).

\begin{tabular}{|c|c|c|c|c|c|}
\hline & & & hent & & Growth \\
\hline & $\overline{\text { Larvae }}$ & Pupae & Females & Males & GR \\
\hline Models & AIC & $\overline{\mathrm{AIC}}$ & $\overline{\mathrm{AIC}}$ & $\overline{\mathrm{AIC}}$ & $\mathrm{AIC}$ \\
\hline Models with random factor & & & & & \\
\hline$y=$ leaf type $\times$ temperature + time $+(1 \mid$ chamber $)$ & 359.1 & 470.4 & 183.5 & 146.1 & -656.38 \\
\hline$y=$ leaf type + temperature + time $+(1 \mid$ chamber $)$ & 360.9 & 468.6 & 183.6 & 147.1 & -658.35 \\
\hline$y=$ temperature + time $+(1 \mid$ chamber $)$ & & 466.7 & & 149.0 & -644.43 \\
\hline$y=$ leaf type + time $+(1 \mid$ chamber $)$ & & & & 149.0 & -659.96 \\
\hline Models without random factor & & & & & \\
\hline$y=$ leaf type $\times$ temperature + time & 357.1 & 468.3 & 181.5 & 144.1 & -656.38 \\
\hline$y=$ leaf type + temperature + time & 358.9 & 466.6 & 181.6 & 145.2 & -658.35 \\
\hline$y=$ temperature + time & & 464.7 & 194.5 & 147.0 & -644.43 \\
\hline$y=$ leaf type + time & & & & 143.8 & -659.96 \\
\hline
\end{tabular}

The best models for our data are those in which all the factors were significant (in bold).

environmental and dietary conditions (Sterner and Elser, 2002; Cross et al., 2003).

\section{Results}

\section{Development and growth of $B$. bifida}

All GLMMs showed the highest AICs compared with other models (Table 1), so effects of fixed factors were tested from the GLMs and LM for development and growth, respectively. The development of B. bifida was strongly affected by temperature (Fig. 1). At $14{ }^{\circ} \mathrm{C}$, the complete development of individuals was achieved in 20 days (for both leaf treatments), while at $9{ }^{\circ} \mathrm{C}$ it took three times as long, with a small delay for the individuals fed on eucalypt leaves (i.e., 64 days for eucalypt treatments vs. 56 days for alder). The number of B. bifida larvae differed between temperatures and leaf types (Table 1). There was a higher proportion of B. bifida at the larval stage vs. the pupal stage at $9{ }^{\circ} \mathrm{C}$ than at $14^{\circ} \mathrm{C}(z=6.008$, $P<0.001)$, and in eucalypt than in alder treatments $(z=2.978, P<0.001)$, indicating that larvae developed to pupa more slowly at colder temperatures and when fed on eucalypt vs. alder leaves.

The onset of pupation was delayed by temperature, but not significantly delayed by leaf type (Tables 1 and 2). Pupation started approximately $8-13$ days earlier at $14{ }^{\circ} \mathrm{C}$ than at $9{ }^{\circ} \mathrm{C}$, independent of leaf type (Fig. 1(A), Table 2). The number of pupae was affected by temperature (Table 1). There were fewer pupae in those chambers incubated at $9{ }^{\circ} \mathrm{C}(z=-4.355, P<0.001)$ than in those reared at $14^{\circ} \mathrm{C}$, without a significant effect of the leaf type $(z=-0.315, P=0.753)$.

The onset of adults followed a similar pattern (Fig. 1(B)). In treatments with alder leaves, the onset of adults was 22 days earlier at $14^{\circ} \mathrm{C}$ than at $9{ }^{\circ} \mathrm{C}$, while in treatments with eucalypt, the onset time was 17 days
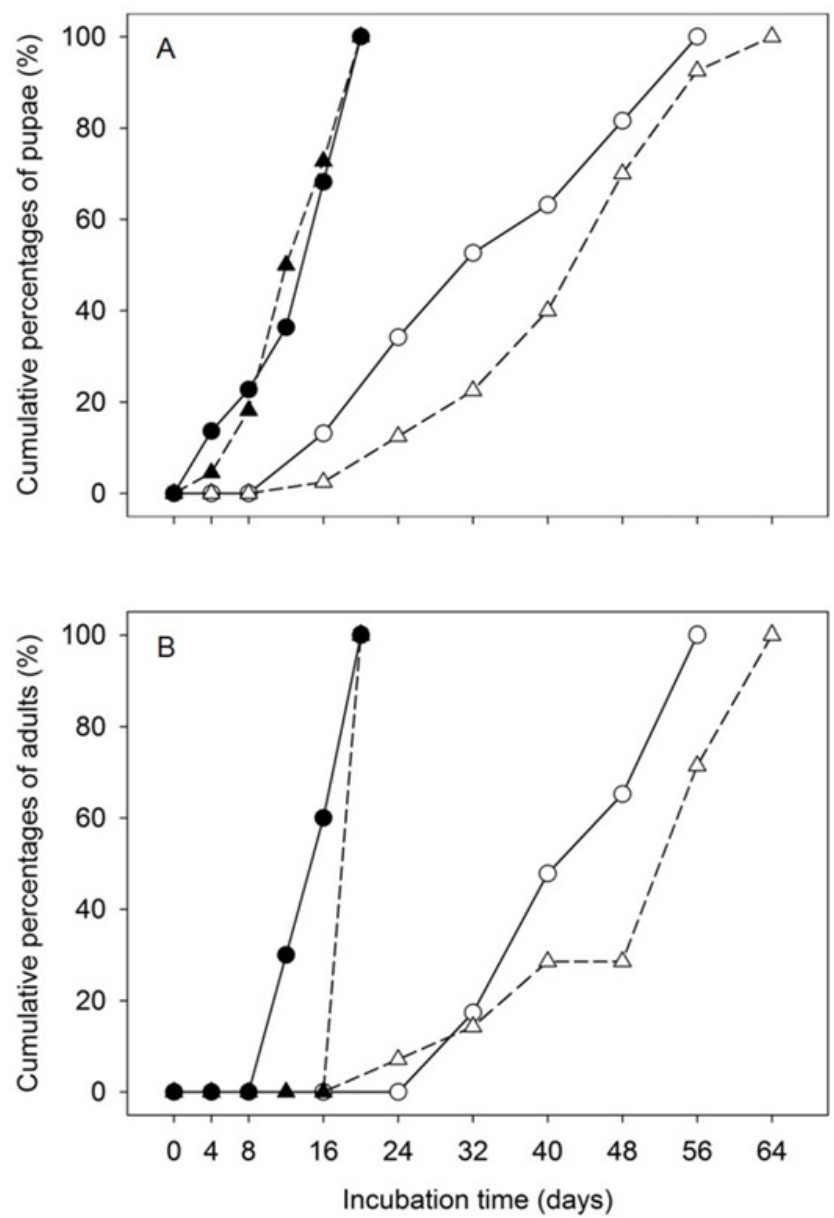

Fig. 1. Cumulative frequencies of maturate specimens of Brillia bifida, during the experiment in each treatment (pupae (A) and adults (B)). Each temperature is represented by colours: $9^{\circ} \mathrm{C}$ (white) and $14{ }^{\circ} \mathrm{C}$ (black), and leaf types by symbols: alder (circle) and eucalypt (triangle). 
Table 2. Developmental-growth parameters (onsetpupae, onsetadults, \%females and \% males, mean \pm SE) estimated for all Brillia bifida individuals sampled during the whole incubation period in each treatment. Growth rates (GR) represents the relative GR of B. bifida larvae during the experiment.

\begin{tabular}{llccrrr}
\hline Treatment & & Onset pupa (days) & Onset adult (days) & Females (\%) & Males (\%) $^{\text {GR (mg.day }}$ Gr) $^{-1}$ \\
\hline $9{ }^{\circ} \mathrm{C}$ & Alder & $16.0 \pm 0.0$ & $34.7 \pm 2.7$ & $65.1 \pm 2.1$ & $34.9 \pm 2.0$ & $0.0430 \pm 0.0053$ \\
& Eucalypt & $21.3 \pm 2.7$ & $37.3 \pm 9.6$ & $49.6 \pm 1.6$ & $50.3 \pm 1.3$ & $0.0160 \pm 0.0042$ \\
$14{ }^{\circ} \mathrm{C}$ & Alder & $8.0 \pm 4.0$ & $13.3 \pm 1.3$ & $59.0 \pm 1.8$ & $40.9 \pm 3.2$ & $0.0400 \pm 0.0125$ \\
& Eucalypt & $8.0 \pm 2.3$ & $20.0 \pm 0.0$ & $100.0 \pm 0.0$ & $0.0 \pm 0.0$ & $0.0106 \pm 0.0068$ \\
\hline
\end{tabular}

earlier (Table 2). The number of females emerging from chambers incubated at $9^{\circ} \mathrm{C}$ was significantly lower $(z=-2.411, \quad P<0.001)$ than those emerging from chambers incubated at $14^{\circ} \mathrm{C}$ (Tables 1 and 2), with no significant differences between leaf types $(z=-1.018$, $P=0.308)$. None of the factors had a significant effect on males (Table 1), but no males emerged from eucalypt chambers at warm temperatures (Table 2). Detritivore GR differed between leaf types, but not between temperatures (Table 1 and Fig. 2). GR were lower for those individuals fed on eucalypt leaves than on alder leaves $(t=-2.747$, $P<0.001)$.

\section{Elemental content}

B. bifida larvae had a high nutrient content in comparison with leaves (Table 3 ), indicating potential elemental imbalances between B. bifida and its food

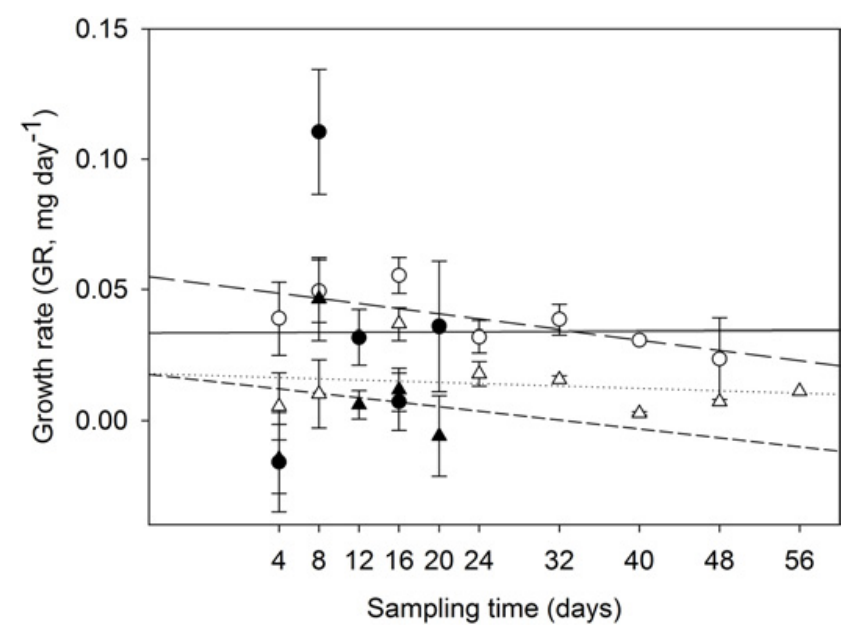

Fig. 2. Growth rates (GR) of Brillia bifida larvae incubated under different treatments during the experiment. Each temperature is represented by colours: $9{ }^{\circ} \mathrm{C}$ (white) and $14^{\circ} \mathrm{C}$ (black), and leaf types by symbols: alder (circle) and eucalypt (triangle). resource. Moreover, leaf types differed significantly on its initial nutrient content, with values of nitrogen and phosphorus three times higher in alder than in eucalypt leaves (Table 3). Alder leaves had higher quality than eucalypt leaves as indicated by their lower $\mathrm{C}: \mathrm{N}$ ratio (A. glutinosa: $22.82 \pm 0.30 ;$ E. globulus: $72.37 \pm 4.51$ ). However, there was no significant difference on nutrient ratios between treatments for B. bifida (Kruskal-Wallis ANOVA, $P>0.05)$. Despite this lack of differences, B. bifida larvae showed a trend for $\mathrm{C}: \mathrm{N}$ homeostasis (Fig. 3(A)) while C:P and N:P of larvae were more variable depending on the treatments, indicating that larvae may be less homeostatic with $\mathrm{P}$ than with $\mathrm{N}$ changes (Figs. 3(B) and $(\mathrm{C})$.

\section{FPOM production of $B$. bifida}

FPOM production by larvae depended on the interaction between food quality and temperature $(t=2.602$, $P<0.001)$. The lowest amount of FPOM production was observed in the treatment with eucalypt leaves at $14{ }^{\circ} \mathrm{C}$. Moreover, the $\mathrm{C}: \mathrm{N}$ ratio of the FPOM produced by $B$. bifida larvae also depended on the interaction between food quality and temperature $(t=3.855, \quad P<0.001)$. Indeed, the FPOM produced in chambers with eucalypt leaves at $9{ }^{\circ} \mathrm{C}$ showed the highest $\mathrm{C}: \mathrm{N}$ ratio, and thus the FPOM produced in these chambers showed a low $\mathrm{N}$ content (Fig. 4).

\section{Discussion}

We highlighted here the effect of food type and temperature as factors controlling the life history of a dominant chironomid species through its influence on different developmental-growth parameters and its elemental composition, thus with potential effects on the species' fitness and its role in stream functioning. Chironomids develop quickly and reach a reproductive

Table 3. Nutrient content, expressed as percentages (mean $\pm \mathrm{SE}$ ), of larvae of Brillia bifida and leaves of Alnus glutinosa and Eucalyptus globulus at the beginning of the experiment (time $=0)$.

\begin{tabular}{lrrr}
\hline & Brillia bifida & Alnus glutinosa & Eucalyptus globulus \\
\hline$\% \mathrm{C}$ & $40.95 \pm 5.66$ & $54.88 \pm 1.03$ & $53.83 \pm 0.51$ \\
$\% \mathrm{~N}$ & $8.62 \pm 0.91$ & $2.81 \pm 0.02$ & $0.87 \pm 0.05$ \\
$\% \mathrm{P}$ & $1.17 \pm 0.19$ & $0.16 \pm 0.03$ & $0.05 \pm 0.02$ \\
\hline
\end{tabular}



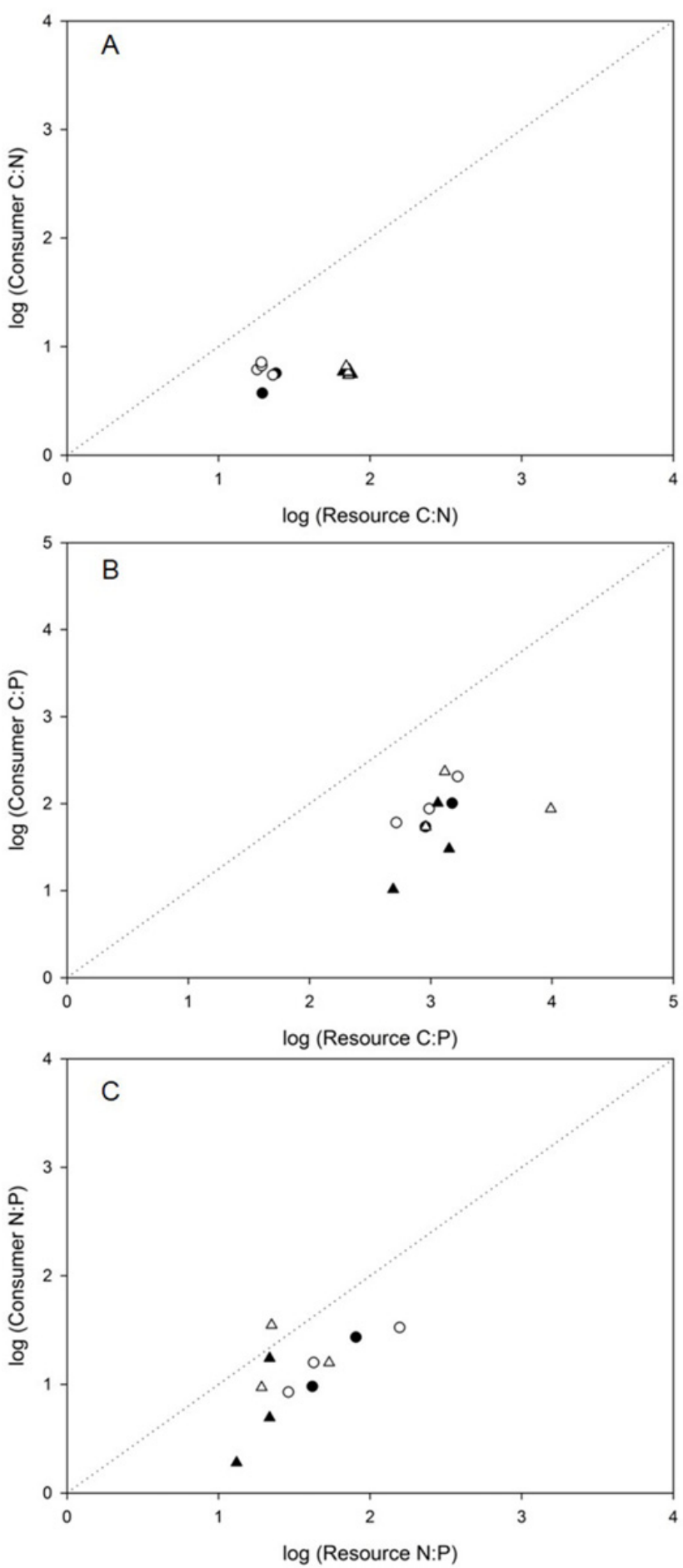

Fig. 3. Molecular elemental ratios of consumer vs. resource (log $\mathrm{C}: \mathrm{N}, \mathrm{C}: \mathrm{P}$, and $\mathrm{N}: \mathrm{P}$ ratios). The dotted diagonal line shows the 1:1 relation. Each temperature is represented by colours: $9^{\circ} \mathrm{C}$ (white) and $14{ }^{\circ} \mathrm{C}$ (black), and leaf types by symbols: alder (circle) and eucalypt (triangle).

stage earlier than most other stream insects by maximizing energy acquisition during larval stages and minimizing the duration of adulthood (Tokeshi, 1995). In our study, developmental parameters were highly determined by

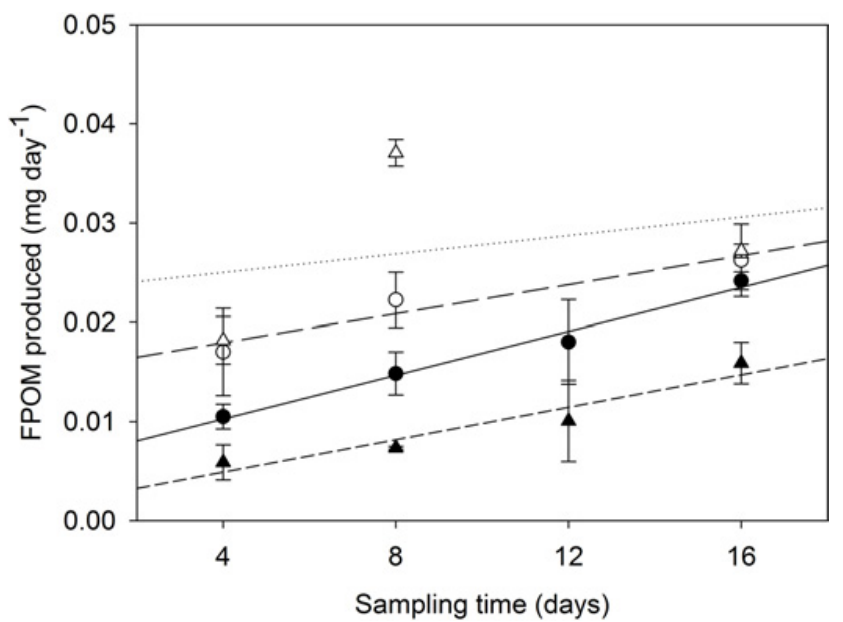

Fig. 4. Quantity of fine particulate organic matter (FPOM) produced by Brillia bifida larvae incubated under different treatments during the experiment. Each temperature is represented by colours: $9{ }^{\circ} \mathrm{C}$ (white) and $14{ }^{\circ} \mathrm{C}$ (black), and leaf types by symbols: alder (circle) and eucalypt (triangle).

temperature, as hypothesized at the beginning of the experiment. Indeed, II-instar B. bifida larvae completed their life cycle within 20 or 56-64 days, depending on whether the temperature was 14 or $9^{\circ} \mathrm{C}$, respectively (i.e., three times as rapidly). This result is within the range of values reported for other chironomids (Nebeker, 1973; Mackey, 1977; Hauer and Benke, 1991), and suggests that B. bifida has great phenotypic plasticity in the completion of its life cycle compared with other insect species (Nylin and Gotthard, 1998; Metcalfe and Monaghan, 2001). A previous field study carried out in this area suggested that $B$. bifida has a multivoltine life cycle with a single cycle having a duration of less than 38 days during springsummer, and with indistinctive cohorts developing during autumn-winter (García and Pardo, 2012).

The present study elucidates different effects of temperature and food type on B. bifida performance. For example, there were always fewer adults emerging from chambers supplied with eucalypt leaves than from those with alder leaves. Moreover, we found a total absence of males in eucalypt treatments at $14{ }^{\circ} \mathrm{C}$, which might indicate that eucalypt leaves are promoting "sub-optimal" conditions for this dominant detritivore. In all treatments, females were more abundant than males, which could reflect unbalanced sex ratios for this species in its natural habitat. In temperate areas there is no evidence for unbalanced sex ratios in most species (Delettre and Morvan, 2000), but in the Arctic, females of most Orthocladiinae species can outnumber males (Oliver and Danks, 1972). Since males can mate with more than one female, it is difficult to discern whether this would constrain the fitness of $B$. bifida populations or not.

GR of B. bifida larvae were affected by leaf type. Different conditioning times of leaves ( 7 days for alder vs. 14 days for eucalypt) may have also underestimated the real differences between leaves. GR of B. bifida larvae were 
three times greater when fed alder leaves than when fed eucalypt leaves, likely due to the lower nutritional quality of eucalypt leaves. Generally, the presence of toxic compounds and/or strong leaf cuticle (as in eucalypt leaves) can act as barriers to leaf-shredding detritivores (Canhoto and Graça, 1995, 1999; Graça et al., 2002), while high nutritional quality enhances growth and fitness of many species (Stout et al., 1993; Hutchens et al., 1997; Huryn and Wallace, 2000). A recent study demonstrated that the direct consumption of eucalypt leaf litter rather than leachates is what negatively affects detritivore GR (Correa-Araneda et al., 2015). Similarly, detritivore fitness was only affected by single stressors in our study. Indeed, development was mainly influenced by temperature, and GR by leaf type; no interactive effects arose in our experiments. However, even though our analyses were truncated (i.e., some larvae pupated too soon in some treatments or not enough material to be analysed), we observed joint effects of leaf type and temperature on $B$. bifida's stoichiometry, and on larvae-mediated nutrient transformations in terms of the quantity and quality of the FPOM produced.

According to stoichiometric regulation, digestion and absorption may be adjusted to favour the retention of a limiting element, with excess nutrients being released via excretion or respiration (Anderson et al., 2005). Consequently, the extent to which individuals can to compensate for this imbalance will ultimately determine the constraints on an individual's performance and survival, as well as alterations in the consumers' nutrient cycling (Sterner and Elser, 2002). Recent studies have shown that the degree to which shredders modify FPOM stoichiometry from CPOM stoichiometry may also vary across shredder species depending on traits such as nutritional requirements or feeding behaviour when reared under different leaf types and temperatures (Villanueva et al., 2011; Mas-Martí et al., 2015; Correa-Araneda et al., 2015). The order Diptera is known to have a high $\mathrm{P}$ content, although paradoxically, detritus is among the most P-deficient of food resources (Cross et al., 2003; Evans-White et al., 2005). In our detritus-based system, we confirmed that $B$. bifida larvae are clearly far out of stoichiometric balance with their food resources, mostly in eucalypt treatments (where the highest elemental imbalances occurred). B. bifida larvae seemed to exhibit strong $\mathrm{C}: \mathrm{N}$ homeostasis, despite differences on resource stoichiometry. Homeostasis could be achieved by activation of different physiological mechanisms (e.g., to selectively retain the elements they need from food and to eliminate the elements in excess), as has been suggested for other similar taxonomic groups and other detritivore species in lakes and streams (Frost et al., 2003; Evans-White et al., 2005; Balseiro and Albariño, 2006; Villanueva et al., 2011). Despite our findings of no significant effect of temperature and food type on larvae elemental ratios, our data suggest different trends for $B$. bifida nutrient ratios. Moreover, the quantity and quality of FPOM produced by B. bifida larvae were also influenced by the joint effect of food type with temperature. These results are in line with our prediction that both factors together may constrain detritivore fitness due to the mismatch between metabolic demands and availability of resources, with potential consequences for many ecosystem processes (e.g., nutrient cycling).

In short, differential effects observed on larval development, growth and elemental composition point out that food resource and temperature are influencing B. bifida performance, a dominant shredder of NW Spain forested headwaters. The fact that the development of a numerically dominant shredder can be challenged by human alteration of the resources they eat indicates how specific and alterable the relationships between stream consumers and resources can be.

Acknowledgements. We thank John S. Richardson, Marcin W. Wojewodzic and two anonymous referees for revising this manuscript. We are grateful to Mø del Mar Domínguez, Alberto Couñago for their help in chemical analyses, and Aldo Barreiro Felpeto for his advices and help with statistical analyses. John S. Richardson and Kasey Moran helped edit the English.

\section{References}

Abelho M. and Graça M.A.S., 1996. Effects of eucalyptus afforestation on leaf litter dynamics and macroinvertebrate community structure of streams in central Portugal. Hydrobiologia, 324, 195-204.

Anderson T.R., Hessen D.O., Elser J.J. and Urabe J., 2005. Metabolic stoichiometry and the fate of excess carbon and nutrients in consumers. Am. Nat., 165, 1-15.

Atkinson D., 1994. Temperature and organism size: a biological law for ectotherms? Adv. Ecol. Res., 25, 1-58.

Balseiro E.G. and Albariño R.J., 2006. C-N mismatch in the leaf litter-shredder relationship of an Andean Patagonian stream detritivore. J. N. Am. Benth. Soc., 25, 607-615.

Bärlocher F., Canhoto C. and Graça M.A.S., 1995. Fungal colonization of alder and eucalypt leaves in two streams in Central Portugal. Archiv. Hydrobiol., 133, 457-470.

Bates D., Maechler M. and Bolker B., 2011. lme4: Linear mixedeffects models using S4 classes. R package version 0.999375 42. http://CRAN.R-project.org/package=lme4.

Brown J.H., Gilloly J.F., Allen A.P., Savage V.M. and West G.B., 2004. Toward a metabolic theory of ecology. Ecology, $85,1771-1789$.

Canhoto C. and Graça M.A.S., 1995. Food value of introduced eucalypt leaves for a Mediterranean stream detritivore Tipula lateralis. Freshwat. Biol., 34, 209-214.

Canhoto C. and Graça M.A.S., 1996. Decomposition of Eucalyptus globulus leaves and tree native leaf species (Alnus glutinosa, Castanea sativa and Quercus faginea) in a Portuguese low order stream. Hydrobiologia, 333, 79-85.

Canhoto C. and Graça M.A.S., 1999. Leaf barriers to fungal colonization and shredders (Tipula lateralis) consumption of decomposing Eucalyptus globulus. Microbial Ecology, 37, 163-172.

Canhoto C., Bärlocher F. and Graça M.A.S., 2002. The effects of Eucalyptus globulus oils on fungal enzymatic activity. Archiv für Hydrobiologie, 154, 121-132. 
Cillero C., Pardo I. and López E.S., 1999. Comparisons of riparian vs over stream trap location in the estimation of vertical litterfall inputs. Hydrobiologia, 416, 171-179.

Correa-Araneda F., Boyero L., Figueroa R., Sánchez C., Abdala R., Ruiz-García A. and Graça M.A.S., 2015. Joint effects of climate warming and exotic litter (Eucalyptus globulus Labill.) on stream detritivore fitness and litter breakdown. Aquat. Sci., 77, 197-205.

Cranston P.S., Oliver D.R. and Saether O.A., 1983. The larvae of Orthocladiinae (Diptera: Chironomidae) of the Holarctic region. Keys and diagnoses. In: Wiederholm T. (ed.), Chironomidae of the Holarctic Region. Part 1. Larvae. Entomologica Scandinavica Supplement, Lund, Sweden, 149-291.

Cross W.F., Benstead J.P., Rosemond A.D. and Wallace J.B., 2003. Consumer-resource stoichiometry in detritus-based streams. Ecol. Lett., 6, 721-732.

Cummins K.W. and Klug M.J., 1979. Feeding ecology of stream invertebrates. Ann. Rev. Ecol. Evol. Syst., 10, 147-172.

Cummins K.W., Wilzbach M.A., Gates D.M., Perry J.B. and Taliaferro W.B., 1989. Shredders and riparian vegetation. Bioscience, 39, 24-30.

Delettre Y.R. and Morvan N., 2000. Dispersal of adult aquatic Chironomidae (Diptera) in agricultural landscapes. Freshwat. Biol., 44, 399-411.

Development Core Team R., 2012. A Language and Environment for Statistical Computing (version 2.15.2) R Foundation for Statistical Computing, Vienna, Austria.

Dieterich M. and Anderson N.H., 2000. The invertebrate fauna of summer-dry streams in western Oregon. Archiv. Hydrobiol., 147, 273-295.

Evans-White M.A., Stelzer R.S. and Lamberti G.A., 2005. Taxonomic and regional patterns in benthic macroinvertebrate elemental composition in streams. Freshwat. Biol., 50, 1786-1799.

Fisher S.G. and Likens G.E., 1973. Energy flow in Bear Brook, New Hampshire: an integrative approach to stream ecosystem metabolism. Ecol. Monogr., 43, 421-439.

Frost P.C., Tank S.E., Turner M.A. and Elser J.J., 2003. Elemental composition of littoral invertebrates from oligotrophic and eutrophic Canadian lakes. J. N. Am. Benth. Soc., $22,51-62$.

Frost P.C., Evans-White M.A., Finkel Z.V., Jensen T.C. and Matzek V., 2005. Are you what you eat? Physiological constraints on organismal stoichiometry in an elementally imbalanced world. Oikos, 109, 18-28.

García L. and Pardo I., 2012. On the way to overcome some ecological riddles of forested headwaters. Hydrobiologia, 696, 123-136.

Gessner M.O., Chauvet E. and Dobson M., 1999. A perspective on leaf litter breakdown in streams. Oikos, 85, 377384.

Gomi T., Sidle R.C. and Richardson J.S., 2002. Headwater and network systems: understanding the processes and downstream linkages of headwater systems. Bioscience, 52, 905-916.

Graça M.A.S., 2001. The role of invertebrates on leaf litter decomposition in streams - a review. Int. Rev. Hydrobiol., 86, 383-393.

Graça M.A.S., Pozo J., Canhoto C. and Elosegi A., 2002. Effects of Eucalyptus plantations on detritus, decomposers, and detritivores in streams. Sci. World J., 2, 1173-1185.

Grasshoff K., Ehrhardt M. and Kremling K., 1983. Methods of Seawater Analysis, Verlag Chemie, Weinheim, 317 p.

Hauer F.R. and Benke A.C., 1991. Rapid growth of snagdwelling chironomids in a blackwater river: the influence of temperature and discharge. J. N. Am. Benth. Soc., 10, 154-164.

Hildrew A.G., Raffaelli D.G. and Edmons-Brown R., 2007. Body Size: The Structure and Function of Aquatic Ecosystems, Cambridge University Press, Cambridge, UK.

Huryn A.D. and Wallace J.B., 2000. Life history and production of stream insects. Ann. Rev. Entomol., 45, 83-110.

Hutchens J.J., Benfield E.F. and Webster J.R., 1997. Diet and growth of a leaf-shredding caddisfly in southern Appalachian streams of contrasting disturbance history. Hydrobiologia, 346, 193-201.

Kling C., 2012. Analysis of eucalyptus plantations on the Iberian Peninsula. Master Thesis. Uppsala: SLU, Dept. of Forest Products, $80 \mathrm{p}$.

López E.S., Pardo I. and Felpeto N., 2001. Seasonal differences in green leaf breakdown and nutrient content of deciduous and evergreen tree species and grass in a granitic headwater stream. Hydrobiologia, 464, 51-61.

Mackey A.P., 1977. Growth and development of larval Chironomidae. Oikos, 28, 270-275.

Mas-Martí E., Romaní A.M. and Muñoz I., 2015. Consequences of warming and resource quality on the stoichiometry and nutrient cycling of a stream shredder. PLOS ONE, 10, e0118520. doi: 10.1371/journal.pone.0118520.

Metcalfe N.B. and Monaghan P., 2001. Compensation for a bad start: grow now, pay later? Trends Ecol. Evol., 16, 254-260.

Nebeker A.V., 1973. Temperature requirements and life cycle of the midge Tanytarsus dissimilis (Diptera: Chironomidae). J. Kansas Entomol. Soc., 46, 160-165.

Nylin S. and Gotthard K., 1998. Plasticity in life-history traits. Ann. Rev. Entomol., 43, 63-83.

Oliver D.R. and Danks H.V., 1972. Sex ratios of some high arctic Chironomidae (Diptera). Can. Ent., 104, 1413-1417.

Pozo J., Basaguren A., Elosegi A., Molinero J., Fabre E. and Chauvet E., 1998. Afforestation with Eucalyptus globulus and leaf litter decomposition in streams of northern Spain. Hydrobiologia, 373, 101-109.

Quinn G. and Keough M., 2002. Experimental Design and Data Analysis for Biologists, Cambridge University Press, Cambridge, UK.

Richardson J.S., 1991. Seasonal food limitation of detritivores in a montane stream: an experimental test. Ecology, 72, 873-887.

Rowe L. and Ludwig D., 1991. Size and timing of metamorphosis in complex life-cycles: time constraints and variation. Ecology, 72, 413-427.

Slansky F. and Scriber J.M., 1985. Food consumption and utilization. In: Kerkut G.A. and Gilbert L.I. (eds.), Comprehensive Insect Physiology Biochemistry and Pharmacology, Pergamon Press, USA, 87-163.

Small G.E. and Pringle C.M., 2010. Deviation from strict homeostasis across multiple trophic levels in an invertebrate consumer assemblage exposed to high chronic phosphorus enrichment in a Neotropical stream. Oecologia, $162,581-590$. 
Sterner R.W. and Elser J.J., 2002. Ecological Stoichiometry: the Biology of Elements from Molecules to the Biosphere, Princeton University Press, UK.

Stout B.M., Benfield E.F. and Webster J.R., 1993. Effects of a forest disturbance on shredder production in Southern Appalachian headwater streams. Freshwat. Biol., 29, 59-69.

Swan C.M. and Palmer M.A., 2006. Composition of speciose leaf litter alters stream detritivore growth, feeding activity and leaf breakdown. Oecologia, 147, 469-478.

Sweeney B.W. and Vannote R.L., 1986. Growth and production of a stream stonefly: influences of diet and temperature. Ecology, 67, 1396-1410.

Tokeshi M., 1995. Life cycles and population dynamics. In: Armitage P.S., Cranston P.S. and Pinder L.C.V. (eds.), The Chironomidae. The Biology and Ecology of Non-biting Midges, Chapman and Hall, London, 225-234.

Villanueva V.D., Albariño R. and Canhoto C., 2011. Detritivores feeding on poor quality food are more sensitive to increased temperatures. Hydrobiologia, 678, 155-165.
Vos J.H., Ooijevaar M.A.G., Postma J.F. and Admiraal W., 2000. Interaction between food availability and food quality during growth of early instar chironomid larvae. J. N. Am. Benthol. Soc., 19, 158-168.

Wallace J.B. and Webster J.R., 1996. The role of macroinvertebrates in stream ecosystem function. Ann. Rev. Entomol., 41, $115-139$.

Wallace J.B., Eggert S.L., Meyer J.L. and Webster J.R., 1997. Multiple trophic levels of a forested stream linked to terrestrial litter inputs. Science, 277, 102-104.

Webster J.R., Wallace J.B. and Benfield E.F., 1995. Organic processes in streams of the Eastern United States. In: Cushing C.E., Cummins K.W. and Minshall G.W. (eds.), River and stream ecosystems, Ecosystems of the World, Elsevier, Amsterdam, 117-187.

Woodward G., Perkins D.M. and Brown L.E., 2010. Climate change and freshwater ecosystems: impacts across multiple levels of organization. Phil. Trans. Royal. Soc. B. Biol. Sci., $365,2093-2106$. 